\title{
Extent and Determinants of Poverty among Rural Non-Farm Workers in Punjab
}

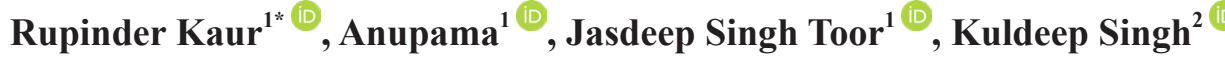 \\ ${ }^{1}$ Department of Economics, Punjabi University, Patiala, India \\ ${ }^{2}$ Department of Post Graduate Studies, Punjabi University Regional Centre, Bathinda, India \\ Email: rupinderkaur0076@gmail.com
}

Received: 19 July 2021; Revised: 20 October 2021; Accepted: 8 December 2021

\begin{abstract}
The economy of Punjab has been undergoing the process of structural change. The share of the primary sector in total employment has declined at a slower rate. Trends have that people are shifting to the non-farm sector as there is little potential in the agricultural sector to generate additional employment opportunities. The number of nonfarm workers is increasing continuously in Punjab. In the non-farm sector, most of the regular jobs are being created in manufacturing and services. The non-manufacturing sector is mainly creating casual employment opportunities. In this background, the present paper examines the poverty status of the rural non-farm workers in Punjab. Using a sample of 659 households from the three districts of Punjab, the study reveals that about 19 percent of the non-farm workers live below the poverty line and 5.27 percent are extremely poor. The incidence of poverty is higher among the SC households than other castes. The workers, who are employed in casual jobs, are more prone to poverty. The greatest proportion of those living below the poverty line can be found in the case of the workers employed in brick kilns and in electronics repair works. About 37 percent of those working as construction workers, loaders in the grain market or in MGNREGS, are living below the poverty line. All of the wage workers in these three categories are poor and vulnerable. The proportion of non-poor workers increases and that of living below the poverty line declines with the increase in the level of education and increase in the size of land ownership.
\end{abstract}

Keywords: poverty, wage workers, MGNREGS, level of education, ownership of land

JEL Codes: D63, I32, P36, Q15

\section{Introduction}

Agriculture has remained the main occupation of the Punjab state till the mid-1980s, after which, it has stopped providing a significant dent to the poverty levels in the state (Datt \& Ravallion, 1998). As the growth of agriculture in the state is slowing down, the development of the non-farm sector is assuming greater importance as compared to the previous decades. The development of the non-farm sector in the state is being emphasized not only to find new avenues of growth and employment but also for increasing the potential sustainability of natural resources which had been in danger due to decades of over-dependence upon agriculture. The development of non-farm activities is an important adaptive strategy in rural areas to increase family income, spread risk, stable salaries, reduce income inequalities to cope

Copyright (C2021 Rupinder Kaur, et al.

DOI: https://doi.org/10.37256/redr.2220211049

This is an open-access article distributed under a CC BY license

(Creative Commons Attribution 4.0 International License)

https://creativecommons.org/licenses/by/4.0/ 
up to the income differentials and give them the security of control over productive resources (Subramanian, 2017).

The extreme poverty in rural India shows a high growth level, especially in the agricultural sector. This poverty can be explained through an unequal distribution of land, water as well as added value, that is deeply entrenched in social relations of dependency (Claire et al., 2015). Non-farm employment is considered to be important to the weaker sections, such as landless as well as small and marginal farmers. The growth of real per capita output in nonagricultural sector can have a significant impact in reducing rural poverty (Coppard, 2001). The jobs in the nonagricultural sector are receiving greater attention in rural areas and give rise to renewed hopes of moving out of poverty (Nayyar \& Sharma, 2005). The earnings from alternative non-farm activities can improve the quality of life among rural households. But, non-farm income reduces poverty (Iqbal et al., 2017).

Actually, the studies have shown that the differences in poverty reduction in the country across states have been due to the differences in the structure of the farm and non-farm sector (Datt et al., 2003). There is ample evidence across the world to believe that the growth of the non-farm sector can play a major role in reducing poverty. The countries/ regions that have made substantial progress in poverty reduction, have done it through creation of off-farm opportunities (Stern, 2001). Hence, it is generally believed that higher non-farm output per person lowers poverty. But, a study by Ravallion and Datt (2002) states that the elasticity of poverty to non-farm growth depends on a number of factors, like the initial level of rural development, human capital and other individual characteristics of the non-farm households. In the rural areas, the non-farm activities are dominated by the own account family enterprises. Such enterprises though offer alternative opportunities of employment in the lean agricultural season and so provide an escape from poverty, yet these lack the dynamism of industrial growth.

Thus, we cannot simply generalize that the non-farm employment leads to poverty reduction across all segments of the rural population. Lanjouw and Murgai (2008) show that the impact of the non-farm sector on poverty is unclear as decent non-farm employment is largely associated with education level, social status, type of activity and the nature of the job. Hence, the poor people, due to being disadvantaged on all these fronts, are mainly pushed to low return casual non-farm employment opportunities. This points towards the need to examine the poverty status of the rural nonfarm workers across these categories. In this perspective, the present paper tries to examine the poverty status of the sampled rural non-farm workers in Punjab according to their caste, education status, land owned, type of activity and employment status.

\section{Data and methodology}

For the purpose of present study, the whole state has been divided into three agro-climatic regions-South-West Region, Central Plains Region, and Shivalik Foothills Region. The South-West Region comprises of Bathinda, Barnala, Mansa, Ferozepur, Fazilka, Faridkot, Muktsar and Moga districts. The Central Plains Region constitutes Patiala, Fatehgarh Sahib, Sangrur, Amritsar, Kapurthala, Jalandhar, SBS Nagar (Nawahahr), Tarn Taran and Ludhiana districts. The Shivalik Foothills Region comprises of Hoshiarpur, Pathankot, Gurdaspur, SAS Nagar (Mohali) and Ropar districts. At the first stage, one district from each region, i.e., Bathinda district from the South-West Region; Jalandhar district from the Central Plains Region; and Gurdaspur district from the Shivalik Foothills Region has been selected randomly for the purpose of present study. One village has been selected randomly from each development block of the selected districts. Thus, thirty villages in tota-eight villages from Bathinda district, eleven villages from Jalandhar district and eleven villages from Gurdaspur district have been selected. 659 households were selected randomly from the three districts for the purpose of survey. Out of the total selected 659 households, 238 households from Bathinda district, 238 households from Jalandhar district and 183 households from Gurdaspur district have been selected. It is a crosssectional analysis related to the year 2016-2017.

Planning commission constituted a new expert group under the chairmanship of Dr. C. Rangarajan, in 2012. This group submitted its report in 2014. The poverty line for rural areas per person per month was mentioned as Rs. 1127.48 at 2011-2012 prices. To examine the poverty status, the Expert Group (Rangrajan) Poverty line has been used (GoI, 2014) at constant prices (base year 1986-1987). Accordingly, the per capita expenditure from the survey data is also adjusted at the constant prices. The poverty ratios have been calculated and further divided into 5 sub-groups as defined by NCEUS (2007). According to this definition, a person is 'Extremely Poor' if he/she consumes less than 0.75 of 
official Poverty Line (PL) consumption expenditure; 'Poor' if his/her consumption expenditure lies between the 0.75 PL and the PL; 'Marginally Poor' if he/she is consuming between PL and 1.25 PL; Vulnerable if his/her consumption expenditure is between 1.25 PL and 2 PL and 'Non-Poor' if his/her consumption expenditure is above 2 PL. Finally, the multiple regression analysis has been used to analyze the determinants of poverty. We have used the binary logistic model. The results show the logit coefficients.

\section{Results and discussion}

Table 1. Summary statistics of sampled non-farm households of Punjab

\begin{tabular}{|c|c|c|c|c|c|}
\hline \multicolumn{2}{|c|}{ Description } & \multirow{2}{*}{$\begin{array}{c}\text { Gurdaspur } \\
114 \\
(62.29)\end{array}$} & \multirow{2}{*}{$\begin{array}{c}\text { Jalandhar } \\
121 \\
(50.84)\end{array}$} & \multirow{2}{*}{$\begin{array}{c}\text { Bathinda } \\
187 \\
(78.57)\end{array}$} & \multirow{2}{*}{$\begin{array}{c}\text { All sampled households } \\
422 \\
(64.03)\end{array}$} \\
\hline Religion & Sikhism & & & & \\
\hline & Hinduism & $\begin{array}{c}51 \\
(27.86)\end{array}$ & $\begin{array}{c}116 \\
(48.73)\end{array}$ & $\begin{array}{c}49 \\
(20.58)\end{array}$ & $\begin{array}{c}216 \\
(32.77)\end{array}$ \\
\hline & Christianity & $\begin{array}{c}18 \\
(9.83)\end{array}$ & $\begin{array}{c}1 \\
(0)\end{array}$ & $\begin{array}{c}0 \\
(0)\end{array}$ & $\begin{array}{c}19 \\
(2.88)\end{array}$ \\
\hline & Islam & $\begin{array}{c}0 \\
(0)\end{array}$ & $\begin{array}{c}0 \\
(0)\end{array}$ & $\begin{array}{c}2 \\
(0.84)\end{array}$ & $\begin{array}{c}2 \\
(0.30)\end{array}$ \\
\hline & Total & $\begin{array}{c}183 \\
(100)\end{array}$ & $\begin{array}{c}238 \\
(100)\end{array}$ & $\begin{array}{c}238 \\
(100)\end{array}$ & $\begin{array}{c}659 \\
(100)\end{array}$ \\
\hline \multirow[t]{4}{*}{ Caste } & $\mathrm{SC}$ & $\begin{array}{c}72 \\
(39.34)\end{array}$ & $\begin{array}{c}144 \\
(60.50)\end{array}$ & $\begin{array}{c}85 \\
(35.71)\end{array}$ & $\begin{array}{c}301 \\
(45.67)\end{array}$ \\
\hline & $\mathrm{OBC}$ & $\begin{array}{c}42 \\
(22.95)\end{array}$ & $\begin{array}{c}36 \\
(15.12)\end{array}$ & $\begin{array}{c}63 \\
(26.47)\end{array}$ & $\begin{array}{c}141 \\
(21.39)\end{array}$ \\
\hline & Others & $\begin{array}{c}69 \\
(37.70)\end{array}$ & $\begin{array}{c}58 \\
(24.36)\end{array}$ & $\begin{array}{c}90 \\
(37.81)\end{array}$ & $\begin{array}{c}217 \\
(32.92)\end{array}$ \\
\hline & Total & $\begin{array}{c}183 \\
(100)\end{array}$ & $\begin{array}{c}238 \\
(100)\end{array}$ & $\begin{array}{c}238 \\
(100)\end{array}$ & $\begin{array}{c}659 \\
(100)\end{array}$ \\
\hline \multirow[t]{3}{*}{$\begin{array}{c}\text { Number of } \\
\text { non-farm workers }\end{array}$} & Male & $\begin{array}{c}253 \\
(85.47)\end{array}$ & $\begin{array}{c}343 \\
(82.25)\end{array}$ & $\begin{array}{c}323 \\
(78.59)\end{array}$ & $\begin{array}{c}919 \\
(81.76)\end{array}$ \\
\hline & Female & $\begin{array}{c}43 \\
(14.53)\end{array}$ & $\begin{array}{c}74 \\
(17.75)\end{array}$ & $\begin{array}{c}88 \\
(21.41)\end{array}$ & $\begin{array}{c}205 \\
(18.24)\end{array}$ \\
\hline & Total & $\begin{array}{c}296 \\
(100)\end{array}$ & $\begin{array}{c}417 \\
(100)\end{array}$ & $\begin{array}{c}411 \\
(100)\end{array}$ & $\begin{array}{l}1124 \\
(100)\end{array}$ \\
\hline \multirow[t]{3}{*}{ Literacy } & Illiterate & $\begin{array}{c}52 \\
(17.57)\end{array}$ & $\begin{array}{c}54 \\
(12.95)\end{array}$ & $\begin{array}{c}94 \\
(22.87)\end{array}$ & $\begin{array}{c}200 \\
(17.79)\end{array}$ \\
\hline & Literate & $\begin{array}{c}244 \\
(82.43)\end{array}$ & $\begin{array}{c}363 \\
(87.05)\end{array}$ & $\begin{array}{c}317 \\
(77.12)\end{array}$ & $\begin{array}{c}924 \\
(82.21)\end{array}$ \\
\hline & Total & $\begin{array}{c}296 \\
(100)\end{array}$ & $\begin{array}{c}417 \\
(100)\end{array}$ & $\begin{array}{c}411 \\
(100)\end{array}$ & $\begin{array}{l}1124 \\
(100)\end{array}$ \\
\hline Family-size & & 4.91 & 4.81 & 4.64 & 4.78 \\
\hline
\end{tabular}

Source: Field Survey, 2016

Note: Figures in brackets denote percentage

Among three selected districts, Gurdaspur district is in Majha region of the state of Punjab, having an international border with the Pakistani Punjab. Jalandhar district is in Doaba region of the state of Punjab. A large number of people from this district have immigrated to other countries. Bathinda district is in Malwa region of the state of Punjab. It 
is the second largest district in Punjab and part of cotton belt. The summary statistics of sampled non-farm workers are given in Table 1. The Sikh religion forms 64.03 percent proportion of sampled households, while the proportion for those belonging to the Hindu religion is only 32.77 percent of the sampled non-farm households. The Scheduled Caste category constitutes 45.67 percent of the sample; whereas 21.39 percent of the sample households belong to the backward classes and 32.92 percent households belong to the 'others' caste category. Out of 1124 workers engaged in various non-farm activities in the sampled households, 81.76 percent are males and just 18.24 percent are females. As many as 17.79 percent of rural non-farm workers are illiterate. The proportion of the illiterate workers is the highest in Bathinda district (22.87 percent), followed by in Gurdaspur (16.89 percent) and then Jalandhar (13.43 percent). The average family size of non-farm workers is 4.18 .

\subsection{Poverty status of sampled rural non-farm workers in Punjab}

The distribution of rural non-farm workers in the sampled districts according to their poverty status is given in Table 2. The table shows that out of the total sampled households, only 27.86 percent can be termed as non-poor, while 72.14 percent fall in different categories of poverty. As per the official poverty line, about 19 percent (5.27 plus 13.39 percent) of the sampled non-farm workers live below poverty line and 5.27 percent are extremely poor. Further, we can see that out of total sampled non-farm workers, 16.61 percent are marginally poor and 36.88 percent are vulnerable.

Table 2. District-wise distribution of rural non-farm workers in Punjab according to their poverty status

\begin{tabular}{ccccc}
\hline Poverty status & Bathinda & Gurdaspur & Jalandhar & All \\
\hline Extremely poor & 6.08 & 7.46 & 2.90 & 5.27 \\
Poor & 13.38 & 17.29 & 10.63 & 13.39 \\
Marginally poor & 14.60 & 18.31 & 17.39 & 16.61 \\
Vulnerable & 33.82 & 29.49 & 45.17 & 36.88 \\
Non-poor & 32.12 & 27.46 & 23.91 & 27.86 \\
\hline
\end{tabular}

Source: Field Survey 2016-2017

The district-wise analysis shows that the proportion of the extremely poor non-farm workers is the highest in district Gurdaspur (7.46 percent) and the lowest in district Jalandhar (2.90 percent). Same is the case with the workers falling in the category of 'Poor'. However, as we go with relatively lower degrees of poverty, we can observe that the proportion of the marginally poor is the highest in Gurdaspur district (18.31 percent) and the lowest in Bathinda (14.60 percent). The is due to the reason that Gurdaspur district is a border district and for the reason, less remunerative nonfarm activities have developed in this district. In the case of vulnerable workers, the proportion of districts Bathinda, Gurdaspur and Jalandhar are 33.82, 29.49 and 45.17 percent, respectively. The proportion of the non-poor farm workers has been found to be the highest in Bathinda (32.12 percent), followed by in Gurdaspur (27.46 percent) and then in Jalandhar (23.91 percent). Thus, we have seen that although district Jalandhar has the lowest proportion of the extremely poor workers but the proportion of the non-poor workers is also the lowest in this district. In all the districts, the proportion of the poor is much higher among the sampled rural non-farm workers than the incidence of poverty in the state as a whole, which was merely 8.3 percent for the state as a whole and 7.7 percent in its rural areas during 201112 (GoI, 2014). Thus, the economic growth in India, spontaneously leading the rural poor towards some kind of social advancement, seems highly unrealistic (Claire et al., 2015).

The poverty status of the non-farm workers has a complex relationship with several individual and household level characteristics. The poor are more likely to possess those characteristics (such as caste, education, assets, etc.), which may lead them to low productive and low paid non-farm activities. Caste plays an important role in determining the position of a person on the economic ladder. Historically, the Indian society has a rigid, occupation-based, hierarchical caste system in which the relative place of a caste in the social hierarchy is determined largely by its traditional 
occupation. The majority of the Scheduled Castes are discriminated against in every respect and denied ownership of productive assets like capital, as well as basic rights such as education and equality. This has resulted in the continuation of their extreme socio-economic deprivation (Neha, 2016). The workers belonging to the lower castes are placed to the occupations that are low-paid (Mendelsohn \& Vicziany, 1998) which leads to the higher incidence of poverty. This can also be confirmed by the poverty status of the sampled non-farm workers across social groups which have been displayed in Table 3. The Table shows that the incidence of poverty (extremely poor and poor) is the highest among the SCs. We can see that the proportion of the workers living below the poverty line is the highest among the SCs and the lowest among the 'Other' caste categories. The table shows that about 29 percent of the sampled non-farm workers belonging to the SCs live below the poverty line (extremely poor plus poor) while this proportion is about 18 percent in case of the OBCs and only about 3 percent for 'Others'. Out of those living below the poverty line, the proportion of those living in extreme poverty is 7.78, 5.18 and 1.22 percent for the SCs, OBCs and Others, respectively. Further, we can also note that the combined proportion of the marginally poor and vulnerable is almost similar for the SCs and OBCs (about 57 percent and 59 percent respectively) but it is relatively higher than those belonging to the 'Other' castes category (about 43 percent). On the other hand, the proportion of the non-poor (i.e. those belonging to the middle income group and high income group) is higher in case of 'Others' than SCs and OBCs. The table shows that 53.80 percent of the sampled non-farm workers belonging to the 'Other' caste category are non-poor as compared to only 14.07 percent in case of SCs and 23.51 percent in case of the OBCs. Thus, we can say that about 86 percent of workers belonging to SCs and 76 percent of those belonging to the OBCs suffer from different degrees of poverty while this proportion is 46 percent for 'Others' which represents the maintenance of social hierarchy in the non-agricultural sector as well.

Table 3. Distribution of rural non-farm workers in Punjab according to their poverty status and social groups

\begin{tabular}{cccc}
\hline Poverty status & Scheduled castes & Other backwards castes & Others \\
\hline Extremely poor & 7.78 & 5.18 & 1.22 \\
Poor & 20.93 & 12.75 & 1.52 \\
Marginally poor & 18.15 & 21.51 & 10.33 \\
Vulnerable & 39.07 & 37.05 & 33.13 \\
Non-poor & 14.07 & 23.51 & 53.80 \\
\hline
\end{tabular}

Source: Field Survey 2016-2017

Apart from caste, there are several other factors which may influence the economic status of the non-farm workers in the rural areas. Among these, the employment status can also be an important determinant. The employment in the non-farm sector is highly heterogeneous and hence, the economic status of the rural non-farm workers depends upon their employment status which can be classified into three broader categories viz., self-employed workers, regular workers and the casual workers. The regular workers can be further classified by the sector in which they are employed i.e. regular workers in the government/public sector and regular workers in the private sector. Lanjouw and Shariff (2002) have shown that the regular workers in the non-farm sector are more likely to be placed in the top quintiles of the consumption expenditure while the casual ones fall in the lowest quintiles. Hence, the proportion of the poor workers is higher among the casual workers than those in regular employment. In this perspective, Himanshu et al. (2011) have also pointed towards declining quality of non-farm employment in India due to casualisation of this sector. Table 4 confirms this fact. The table shows that about 35 percent of the casual workers live below the poverty line, out of which 9.46 percent are extremely poor. This segment also has the largest proportion of the people living just above the poverty line (i.e. the marginally poor), while the proportion of the vulnerable population is the highest among the self-employed non-farm workers.

Normally, the regular workers are considered to be better off than any other type of workers but we can see from the Table 4 that this is true only for the regular workers employed in the government sector, while the condition of 
those employed in the private sector is worse than that of the self-employed workers. The proportions of the extremely poor, poor as well as marginally poor are greater for the regular workers in the private sector than the self-employed workers as we can see in the table that these proportions are 5.99, 11.61 and 19.48 percent respectively for the non-farm regular workers in the private sector as compared to $2.97,8.17$ and 13.37 percent respectively for the self-employed workers. The proportion of the vulnerable workers has been found to be the highest among the self-employed workers (40.10 percent), closely followed by among the regular workers in the private sector (39.33 percent) and the casual workers (33.44 percent). Only about 30 percent of the regular workers in the government sector fall in this category. The table also shows that the proportion of the non-poor workers is about 61 percent in case of the regular workers in the government sector as compared to only 8 percent for the casual workers while about 35 percent of the self-employed workers and about 24 percent of the regular workers in the private sector are found to be non-poor. Thus, we can say that about 65, 39, 76 and 92 percent of the sampled self-employed workers, regular workers in government sector, regular workers in the private sector and casual workers, respectively in the rural non-farm sector of Punjab bear some degree of poverty.

Table 4. Distribution of rural non-farm workers in Punjab according to their poverty status (consumption poverty) and status of employment

\begin{tabular}{ccccc}
\hline \multirow{2}{*}{ Poverty status } & Self-employed & \multicolumn{2}{c}{ Regular workers } & Casual workers \\
\cline { 3 - 5 } & & Government sector & Private sector & \\
\hline Extremely poor & 2.97 & 0.76 & 5.99 & 9.46 \\
Poor & 8.17 & 3.79 & 11.61 & 25.55 \\
Marginally poor & 13.37 & 4.55 & 19.48 & 23.34 \\
Vulnerable & 40.10 & 30.30 & 39.33 & 33.44 \\
Non-poor & 35.40 & 60.61 & 23.60 & 8.20 \\
\hline
\end{tabular}

Source: Field Survey 2016-2017

Thus, we have seen that the incidence of poverty is the highest among those who are employed in casual jobs. Actually, there are certain occupations under the broader category of the non-farm sector, which employ the workers more on casual basis than the regular one. Some of these activities require unskilled workers, while some employ the skilled workers mainly. These differences in the type of activity as well as degree of skills required greatly influence the differences in the proportion of the workers bearing different degrees of poverty. We have also seen above that not all the self-employed and regular workers are non-poor. Some of the workers employed in these categories also bear some degree of poverty. It depends upon the type of activity in which they are employed. Hence, it is important to observe the activity-wise distribution of non-farm workers according to their poverty status. This can be observed in Table 5 .

The table shows that among those who are employed as wage labor, the greatest proportion of those living below the poverty line can be found in case of the workers employed in brick kilns (66.67 percent) and in electronics repair works (50 percent), though none of them are living in extreme poverty. About 37 percent of those working as construction workers, loaders in the grain market and in MGNREGS, are living below the poverty line. The highest proportion of the wage labor living in extreme poverty, can be found among those who earn their living mainly from the MGNREGS (15.13 percent), followed by the loaders in the grain market (12.50 percent) and then by the construction workers (10.45 percent). Further, we can observe that the highest proportion of marginally poor workers can be found in case of the wage labor in electronics repairs. Actually, all the workers under this category are either poor or marginally poor. None of the wage workers under this activity has been found to be non-poor. Other categories, which do not have any non-poor worker, are that of working in brick kilns and in grain markets as loaders. All of the wage workers in these three categories are poor and vulnerable. On the other hand, in case of the wage workers working as painters and plumbers, about 19 percent are non-poor or say, 81 percent are poor and vulnerable, while in case of those working in wood works, construction and MGNREGS, the proportion of non-poor workers is $10.53,10.45$ and 4.20 
percent, respectively, meaning thereby that about 89,90 and 96 percent respectively of them are poor and vulnerable. On the other hand, in case of self-employed activities, best of the non-farm activities are found to be those of the builders and dealers of the related materials. About 73 percent of the builders and such dealers are non-poor and none of them is living in extreme poverty. Further, we can see that about 43 and 40 percent of the retailers and those running multiple activities (like photo state and retail trade; retail trade and photography; photography and mobile cards, etc.) respectively are non-poor. However, those running a manufacturing unit (crafts or other cottage industry) are relatively worse off as only about 20 percent of them are non-poor, indicating that 80 percent of them are poor and vulnerable; about 16 percent of them are living below poverty line out of which about 4 percent are living in extreme poverty.

Table 5. Distribution of rural non-farm workers in Punjab according to their poverty status and type of activity

\begin{tabular}{|c|c|c|c|c|c|}
\hline Categories & Extremely poor & Poor & Marginally poor & Vulnerable & Non-poor \\
\hline \multicolumn{6}{|c|}{ Wage labour } \\
\hline Construction workers & 10.45 & 26.12 & 24.63 & 28.36 & 10.45 \\
\hline Brick kiln workers & 0.00 & 66.67 & 22.22 & 11.11 & 0.00 \\
\hline Factory workers & 11.25 & 18.75 & 25.00 & 37.50 & 7.50 \\
\hline Painter and plumber & 0.00 & 26.92 & 19.23 & 34.62 & 19.23 \\
\hline Electronics repairs & 0.00 & 50.00 & 50.00 & 0.00 & 0.00 \\
\hline Wood works & 0.00 & 10.53 & 36.84 & 42.11 & 10.53 \\
\hline Loading labour in grain market & 12.50 & 25.00 & 37.50 & 25.00 & 0.00 \\
\hline Other workers and MGNREGS & 15.13 & 21.85 & 19.33 & 39.50 & 4.20 \\
\hline \multicolumn{6}{|c|}{ Self-employed activities } \\
\hline Retail & 1.14 & 6.29 & 10.86 & 38.86 & 42.86 \\
\hline Workshops and repairs & 5.08 & 5.08 & 6.78 & 50.85 & 32.20 \\
\hline Manufacturing & 3.88 & 12.62 & 21.36 & 42.72 & 19.42 \\
\hline Building works and materials & 0.00 & 9.09 & 9.09 & 9.09 & 72.73 \\
\hline Multiple self-employed activities & 0.00 & 5.00 & 30.00 & 25.00 & 40.00 \\
\hline Others & 8.33 & 11.11 & 5.56 & 38.89 & 36.11 \\
\hline \multicolumn{6}{|c|}{ Regular workers (Services) } \\
\hline Public administration and defence & 0.00 & 5.08 & 10.17 & 23.73 & 61.02 \\
\hline Education & 0.00 & 3.57 & 8.93 & 25.00 & 62.50 \\
\hline Health & 3.23 & 6.45 & 12.90 & 38.71 & 38.71 \\
\hline Transport and storage & 4.44 & 15.56 & 15.56 & 42.22 & 22.22 \\
\hline $\begin{array}{l}\text { Professional, scientific } \\
\text { and technical activities }\end{array}$ & 1.45 & 8.70 & 15.94 & 36.23 & 37.68 \\
\hline Finance and insurance services & 0.00 & 0.00 & 25.00 & 25.00 & 50.00 \\
\hline Other services & 11.11 & 13.13 & 18.18 & 41.41 & 16.16 \\
\hline
\end{tabular}

Source: Field Survey 2016-2017

In case of the self-employed workers running some workshop or repair works, about 10 percent are found to be 
living below poverty line, out of which almost half of them are living in extreme poverty. Although about 32 percent of them are non-poor but quite a high proportion of them i.e., about 51 percent are found to be vulnerable. Thus, we have seen that in rural areas, among various non-farm self-employed activities, manufacturing is the worst performer while that of the builders and dealers of building materials is the best one; the owners of retail shops and those combining various activities at the same place are also working relatively in a better way than those running the workshops and other activities. We have already seen that the proportion of those living below the poverty line is the lowest among regular workers, especially those employed in the government sector. In rural areas, all such reported activities actually fall under services. Again, all the activities under regular jobs are not similar. Under this broader head, public administration and defence, education and finance, and insurance services are the best performers as none of the workers employed in these activities live in extreme poverty, and 61, 63 and 50 percent of the workers employed in these activities, respectively are non-poor. Under the broader head of services, the condition of those employed in transport and storage is the worst. Only 22 percent of the workers employed in this activity are non-poor; 20 percent live below poverty line and about 4 percent of them are living in extreme poverty. Another 16 percent are marginally poor and 42 percent are vulnerable.

The cases of health services as well as professional, scientific and technical services are also interesting as about only 39 percent and 38 percent of them, respectively, are non-poor, meaning thereby that 61 and 62 percent of them respectively are poor and vulnerable; about 10 percent of the workers in both type of the activities are living below poverty line while 13 percent and 16 percent are marginally poor and 39 and 36 percent, respectively are vulnerable. Under Public Administration and Defence as well as Education while none of the workers is living in extreme poverty but 5 and 3 percent of them, respectively are living below poverty line; about 11 percent and 9 percent, respectively are marginally poor and 24 percent and 25 percent, respectively are vulnerable. Hence, it can be stated that although among the rural non-farm activities, the services are the better performers (but not better than those employed as builders and dealers in building materials) but among services also, the workers employed in transport and storage are not doing well.

Thus, we have seen that the incidence of poverty as well as its degrees differ by the employment status as well as type of activity. Khan (2001) states that in order to understand the poverty creation in rural areas and its impact on different segments of population, it is necessary to look at the assets which the poor own. These assets can be physical as well as human. The poor segments of population are greatly inhibited by lower attainments of both types of assets. A majority of them are generally landless and have low level of education and consequently, the returns on their productive assets (whichever they own) are too low to pull them out of the morass of poverty.

Apart from the land, education is considered to be an important tool for eradication of poverty as well as for fairer distribution of income among the rural masses. We too have seen that the activities which have lower poverty rates among the self-employed as well as regular workers, are the ones which require higher level of education or access to other assets, such as land and credit. Many studies have indicated that the level of non-farm income increases with the average level of education of the non-farm workers (e.g. see Otsuka et al., 2010). We know that the rural non-farm sector is highly segmented as far as the skill requirements are concerned and more skilled jobs have lower incidence of poverty. Therefore, it is important to examine how the increase in level of education of the non-farm workers influences their poverty status. This can be observed from Table 6 . The table clearly shows that as the level of education increases, the proportion of the non-poor workers also increases. We can see that only 8.50 percent of the illiterate rural non-farm workers are non-poor as compared to 63.10 percent for those with education level up to graduation or above. It can also be noticed that about 54 percent of the non-farm workers with professional and technical education are non-poor. On the other hand, the incidence of poverty has been found to be declining as the level of education increases. Another 37 percent of the sampled illiterate non-farm workers live below the poverty line which reduces to merely 1.19 percent for those with education level at graduation and above. The table shows that about 31 percent of the non-farm workers with education level up to primary live below the poverty line and this proportion falls to about 19 percent for those with middle level of education and then to about 14 percent and further to 6 percent for those with education level up to matriculation and senior secondary, respectively. Similarly, the proportion of the marginally poor seems to be declining with increase in educational attainment, except for the workers with educational attainments up to senior secondary. Similarly, we can observe that a fewer of the sampled non-farm workers with education level up to graduation \& above as well as with professional and technical education are vulnerable than other education categories. 
Table 6. Distribution of rural non-farm workers in Punjab according to their poverty status and education status

\begin{tabular}{|c|c|c|c|c|c|}
\hline Education status & Extremely poor & Poor & Marginally poor & Vulnerable & Non-poor \\
\hline Illiterate & 15.50 & 21.50 & 20.00 & 34.50 & 8.50 \\
\hline Primary & 10.53 & 20.39 & 24.34 & 28.95 & 15.79 \\
\hline Middle & 3.03 & 15.66 & 18.18 & 41.92 & 21.21 \\
\hline Matriculation & 1.69 & 12.66 & 13.92 & 38.82 & 32.91 \\
\hline Senior secondary & 0.51 & 5.64 & 13.85 & 44.62 & 35.38 \\
\hline Graduation and above & 1.19 & 0.00 & 9.52 & 26.19 & 63.10 \\
\hline $\begin{array}{l}\text { Professional and } \\
\text { technical education }\end{array}$ & 0.00 & 7.41 & 9.26 & 29.63 & 53.70 \\
\hline
\end{tabular}

Source: Field Survey 2016-2017

Apart from education, other physical assets also influence the non-farm income and hence, the poverty status of the workers. High concentration of land ownership and asymmetrical tenancy relations generally become the cause of creation of poverty in rural areas through contraction in alternative employment opportunities (Khan, 2001). Land is an important asset which determines the access to institutional as well as non-institutional credit. Apart from it, the ownership of land not only gives an additional source of income to save the non-farm families from falling in the trap of poverty but also proves to be a social security asset during the contingencies of life. During the survey, it has been found that the families owning bigger size of land are also able to provide higher level of education to its members, which, in turn, find employment in more remunerative sectors apart from earning from leasing out land or from farming activities. This can be confirmed from Table 7. The table shows that the proportion of non-poor workers increases and that of living below poverty line declines with the increase in size of land ownership. Actually, none of the sampled workers owning land above 2.5 acres has been found living below poverty line, while about 22 percent of the landless and about 6 per cent of those owning land less than 2.5 acres are living below poverty line. Among them, 6.23 percent and 0.86 percent, respectively are extremely poor. On the other hand, the table shows that only about 21 percent of the landless non-farm workers were non-poor and this proportion increases to about 557,177 and then 100 percent for those owning land up to 2.5 acres, between 2.5 and 5 acres, 5 to 15.0 acres and 15 acres and above, respectively. This indicates that about 79 percent of the sampled landless non-farm workers is poor as well as vulnerable and this proportion falls to 45 , 29 and 23 percent, respectively for subsequent land ownership categories as depicted in the table. None of the workers owning any land above 15 acres is found to be bearing any degree of poverty.

Table 7. Distribution of rural non-farm workers in Punjab according to their poverty status and ownership of land

\begin{tabular}{cccccc}
\hline $\begin{array}{c}\text { Ownership of land } \\
\text { (In Acres) }\end{array}$ & Extremely poor & Poor & Marginally poor & Vulnerable & Non-poor \\
\hline Landless & 6.23 & 15.47 & 18.47 & 38.99 & 20.84 \\
Up to 2.5 & 0.86 & 5.17 & 6.90 & 31.90 & 55.17 \\
$2.5-5.0$ & 0.00 & 0.00 & 4.76 & 23.81 & 71.43 \\
$5.0-15.0$ & 0.00 & 0.00 & 13.33 & 10.00 & 76.67 \\
15.0 \& above & 0.00 & 0.00 & 0.00 & 0.00 & 100.00 \\
\hline
\end{tabular}

Source: Field Survey 2016-2017

\subsection{Determinants of poverty among rural non-farm workers}

As we have seen above that non-farm sector is a broad and heterogeneous category, so its economic outcomes 
differ according to the type of activity, employment status and other individual characteristics of the non-farm workers such as education level, ownership of land, caste, household size etc. Hence, by running a regression, we can examine the impact of these factors upon the probability of being poor in rural non-farm sector of Punjab. This can be examined from Table 8 .

Table 8. Factors affecting the probability of being poor among non-farm workers

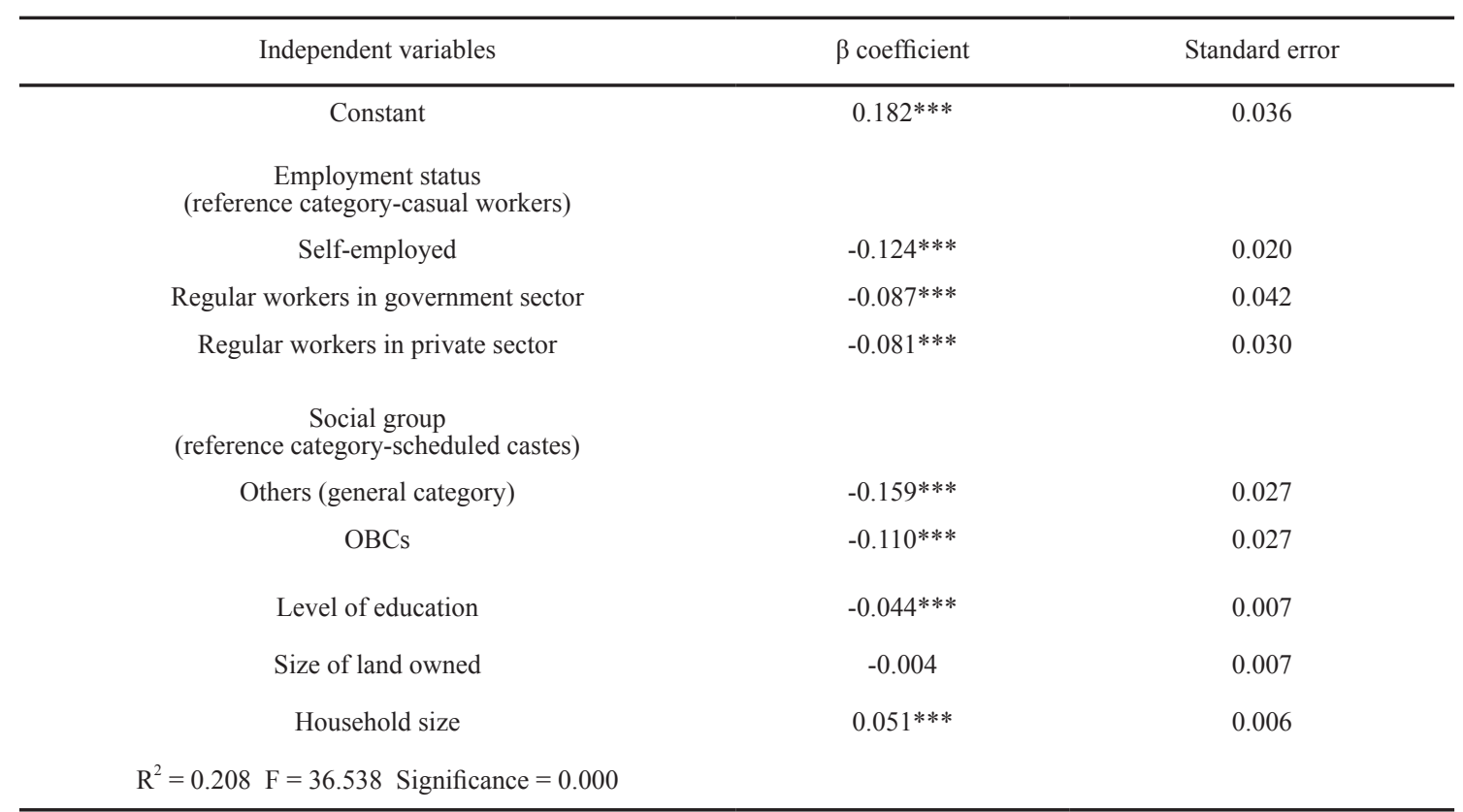

Source: calculated from field survey data $(2016-2017)$

*** significant at 1 percent level of significance $(\mathrm{p}<0.01)$

The table confirms the earlier results that as compared to casual employment, being in self-employment or in regular jobs (both in government and private sector) in rural non-farm sector reduces the probability of being poor. Similarly, as compared to the Scheduled Castes, where the incidence of poverty is very high, belonging to other social groups such as general category (or other caste categories) and OBCs reduces the chances of a non-farm worker in rural areas to fall below the poverty line. Though, the ownership of land does not exhibit any significant impact upon the probability of being poor, yet the level of education reduces it. On the other hand, an increase in household size increases the probability of being poor.

\section{Conclusions and policy implications}

The above analysis shows that the poor in rural non-farm sector are stratified along caste, type of activity, employment status, accumulation of human and physical assets, etc. The incidence of poverty and vulnerability is higher for the non-farm workers belonging to socially marginalised sections and for those working in casual jobs, brick kilns, construction, manufacturing, etc. The non-farm workers with lower educational attainments and no or inadequate land ownership find it hard to come out of poverty and a greater proportion of them remain vulnerable to poverty as compared to the workers with higher level of education and ownership of land above 2.5 acres.

The results of the regression analysis clearly point out the need of spread of education in rural areas, providing incentives to start a non-farm activity and also promoting regular jobs in the government as well as the private sector. There should be an emphasis on promoting higher education in rural areas so that self-employment opportunities become as lucrative as a regular job in the government sector. This needs special focus upon the spread of higher and 
technical education in rural areas. These results also point towards the need of giving some additional incentives to the Scheduled Castes in the rural areas to start their own business instead of relying upon the casual jobs and remain trapped in the vicious cycle of poverty. Thus, by creating more of alternative employment opportunities and ensuring regularity of work, the rural non-farm labour can be pulled out of the muddle of poverty. There is a dire need of a universal social protection system as the rural non-farm workers who earn too less succumb to poverty during any contingency of life.

\section{Note}

This research paper is based on the field survey conducted for a research project "Employment in Rural Non-Farm Sector in Punjab: The Determinants, Problems and Prospects" sponsored by UGC, New Delhi.

\section{Conflict of interest}

The authors have no conflicts of interest to declare. All co-authors have seen and agree with the contents of the manuscript and there is no financial interest to report. We certify that the submission is original work and is not under review at any other publication.

\section{References}

Coppard, D. (2001, November). The rural non-farm economy in India: A review of literature. NRI Report No: 2662. https://assets.publishing.service.gov.uk/media/57a08d67ed915d3cfd0019f0/coppard-2662.pdf

Claire, A., Hugo, L., \& Corentin, L. (2015). Poverty and inequality in rural India. Echo Géo, 32. https://doi.org/10.4000/ echogeo. 14300

Datt, G., \& Martin, R. (1998). Why have some Indian States done better than others at reducing rural poverty? Economica, 65, 17-38.

Datt, G., Kozel, V., \& Ravallion, M. (2003). A model-based assessment of India's progress in reducing poverty in the 1990s. Economic and Political Weekly, 38(4), 355-361.

GoI (2014, June). Report of the Expert Group to Review the Methodology for Measurement of Poverty. Government of India. Planning Commission. https://niti.gov.in/planningcommission.gov.in/docs/reports/genrep/pov_rep0707.pdf

Himanshu, L., Peter, M., Abhiroop, \& Murgai, R. (2011). Non-farm diversification and rural poverty decline: A perspective from Indian sample survey and village study data. Asia Research Centre Working Paper No. 44. London: London School of Economics and Political Science.

Iqbal, M. A., Abbas, A., Ullah, R., Ahmed, U. I., Sher, A., \& Akhtar, S. (2017). Effect of non-farm income on poverty and income inequality: farm households evidence from Punjab province Pakistan. Sarhad Journal of Agriculture, 34(2), 233-239.

Khan, M. H. (2001, March). Rural poverty in developing countries: Implications for Public Policy. Working Paper No. 00/78. Economic Series. International Monetary Fund. http://www.imf.org/external/pubs/ft/issues/issues26/

Lanjouw, P., \& Shariff, A. (2002). Rural non-farm employment in India: Access, incomes and poverty impact. NCAER Working Paper WP020006.

Lanjouw, P., \& Murgai, R. (2008, March). Poverty decline, agricultural wages, and non-farm employment in rural India 1983-2004. Policy Research Working Paper No. 4858. World Bank.

Mendelsohn, O., \& Vicziany, M. (1998). The untouchables: Subordination, poverty and the State in modern India. Cambridge: Cambridge University Press.

Nayyar, R., \& Sharma, A. N. (2005). Rural transformation in India: the role of non-farm sector. Institute for Human Development.

NCEUS (2007). Report on conditions of work and promotion of livelihoods in the unorganised sector. National Commission for Enterprises in the Unorganised Sector. Government of India, New Delhi. http://dcmsme.gov.in/ Condition_of_workers_sep_2007.pdf

Neha, R. (2016). Levels of living of Scheduled Caste households in rural Punjab. Unpublished Ph. D. Thesis, Department of Economics, Punjabi University, Patiala. 
Otsuka, K., Estudillo, Jonna P., \& Yamano, T. (2010). The role of labour markets and human capital in poverty reduction: Evidence from Asia and Africa. Asian Journal of Agriculture and Development, 7(1), 23-40.

Ravallion, M., \& Gaurav, D. (2002). Why has economic growth been more pro-poor in some states of India than others? Journal of Development Economics, 68(2), 381-400.

Stern, N. H. (2001, January). Building a climate for investment, growth and poverty reduction in India. 16th Exim Bank Commencement Day Annual Lecture. Mumbai. https://www.researchgate.net/publication/237343288

Subramanian, S. (2017). Participation of rural households in farm, non-farm and pluri-activity Evidence from India. Working Paper 412. The Institute for Social and Economic Change, Banglore. http://www.isec.ac.in/WP\%20 412\%20-\%20S\%20Subramanian\%20-\%20final.pdf 